\title{
Fasciocutaneous elliptical rotation flap for pilonidal sinus disease and its outcomes
}

\author{
Emre Gündoğdu'(D) \\ 1 Liv Hospital Ankara, General Surgery, Ankara, Turkey
}

\begin{abstract}
Objective: Sacrococcygeal pilonidal sinus is a common disease especially in the Caucasians of the Middle East. It has been reported in the incidence of 12-26 in a 100.000 population. Previously thought to be due to etiological reasons of congenital origin, it is now widely accepted as an acquired disease. The optimal treatment for pilonidal sinus disease still has no consensus. The elliptical rotation flap was first described by Nessar in the surgery of pilonidal sinus and reported successful results, but it has weak points. The purpose of this study was to share the findings of the fasciocutaneous elliptic rotation flap technique retrospectively.
\end{abstract}

Material and Methods: One hundred and eighty-six patients ( 149 were males and 37 were females) operated for pilonidal disease with fasciocutaneous elliptic rotation flap between 2013 and 2018 were included into this study. Data of the patients including operation time, wound issues (infection, seroma, wound separation), time required to return to daily activities, complete healing time and recurrence rates were recorded retrospectively.

Results: The patients' complete healing time was $13 \pm 3$ days and mean follow-up was 19 (6-37) months. Mean operative time was $43 \pm 13$ minutes. Mean time of drain removal was $2.20 \pm 1.18$ days. There were no flap necrosis or ischemia. Postoperative infection developed in two patients (1\%). Seroma developed in 7 (3.8\%) patients. Partial wound dehiscence occurred in $5(3.2 \%)$ patients. None of the cases developed hematoma or complete dehiscence. No recurrence was observed in postoperative follow-ups.

Conclusion: Fasciocutaneous elliptical rotation flap is a method that has follow-up results similar to both the elliptical rotation flap technique and its modification and can be safely preferred in the treatment of pilonidal sinus with its other advantages.

Keywords: Pilonidal sinus disease, elliptical rotation flap, limberg flap, rotation flap

Cite this article as: Gündoğdu E. Fasciocutaneous elliptical rotation flap for pilonidal sinus disease and its outcomes Turk J Surg 2020; 36 (3): 310-316.

Corresponding Author Emre Gündoğdu

E-mail: dremregundogdu@gmail.com

Received: 16.06 .2020

Accepted: 17.09 .2020

Available Online Date: 28.09.2020

o Copyright 2020 by Turkish Surgical Society Available online at www.turkjsurg.com

DOI: $10.47717 /$ turkjsurg.2020.4917

\section{INTRODUCTION}

Pilonidal sinus disease (PSD) was first described by Herbert Mayo in 1883 as a cyst containing hair at the natal cleft (1). Previously, this disease was believed to occur only in the sacrococcygeal region; however, it has been shown that PSD can form in the anal canal, and in the vulvar, umbilical, interdigital and scalp regions $(2,3)$. Sacrococcygeal PSD is common especially in Caucasians of the Middle East (4). PSD can appear as an abscess, a chronic sinus which causes persistent discharge, or a silent cyst in the acute or chronic process (5). PSD has been reported with an incidence of $12-26$ in 100.000 populations $(6,7)$. Studies have shown that PSD is 3-7 times higher in males than females $(4,8,9)$. The disease often occurs around the ages of 15-35 and peaks between the ages of 17-27, and it's rare after 45 years-old (10).

\section{Etiology}

Having been previously considered to be due to etiological reasons of congenital origin (11), PSD is now widely accepted as a disease acquired as a result of presence of hair in the gluteal sulcus (8). According to congenital theory, PSD is thought to be formed either by residual epithelium in the skin and spinal canal or by the introduction of hair follicles into the cavity formed as a consequence of the mal fusion of the dermal layers in the early embryologic period (6). On the other hand, according to the acquired theory, free hairs are gathered at the deep natal cleft, and a follicle penetrates the dermis by the friction power. Later on, a foreign-body reaction happens, and sinus formation takes place at this stage (12). This condition has many predisposing factors, including deep and narrow natal clefts, moist sulcus with chronic skin maceration, fissures or scar tissue at the natal cleft, regional trauma associated with long sitting times, poor hygiene, obesity and hairy body type, and an increased number of free hair follicles $(4,8,13)$. 


\section{Treatment}

The optimal treatment for PSD still has no consensus (5), but ideal treatment should not be technically difficult and be easy to apply, require short hospitalization and provide early return to work and daily routine, ensure better cosmetic results and low cost, and achieve low morbidity and low recurrence.

Non-operative methods such as laser epilation, phenol or fibrin glue injection are used alone or as an adjunct to operative methods in the treatment of PSD. Operative techniques are very diverse; simple excision primary suturing, excision and laying open or marsupialization, Karydakis flap, Bascom technique, Z-plasty, V-Y advancement flap, Limberg flap and its modifications, elliptical rotation flap (ERF) and its modification, gluteus maximus fasciocutaneous flap, vacuum-assisted closure are the most common methods widely used in clinic treatment (14).

Removal of the diseased tissue from the post sacral fascia is similar in all operative techniques, but the main argument is how to close the created defect. In addition to the complete removal of the diseased tissue, the deep intergluteal sulcus, which plays a role in the etiology of the disease, should be elevated and flattened and thus, the accumulation of hair follicles, maceration and fissure formation in this area should be prevented. Moreover, it should be aimed to apply the option of a surgical treatment that does not leave as much scar tissue in midline as possible and does not cause tissue tension in this area (15).

\section{Aim}

Elliptical rotation flap (ERF) was first described by Nessar in the surgery of pilonidal sinus and reported successful results (14). In this described technique, the flap was prepared cutaneously and the root of the flap pedicle was $1 \mathrm{~cm}$ wide. Later on, Dizen et al. and Yoldaş et al. $(16,17)$ modified this technique, using an oblique incision, instead of a vertical incision, to prevent scar tissue formation in the midline and to place the lower edge of the flap 1-2 cm laterally to the natal cleft and to flatten the intergluteal sulcus.

The purpose of this study was to share the findings of the fasciocutaneous elliptic rotation flap (FERF) technique retrospectively, in which we could lateralize the flap edge without disrupting flap viability that would provide less tissue loss.

\section{MATERIAL and METHODS}

One hundred and eighty-six patients operated for PSD with FERF between 2013 and 2018 were included into this study. All patients had chronic pilonidal sinus. Those who had previously been treated with non-operative techniques or those with recurrent disease were excluded from the study. In addition, patients with a disease that negatively affected wound healing (diabetes mellitus, immune deficiencies, etc.) or those who used immunosuppressive therapy for any reason were also excluded.
Informed consent was obtained from the patients by explaining all operative surgical options. Data of the patients were recorded retrospectively. The study protocol was approved by the Committee on Institutional Ethics of Liv Hospital.

\section{Surgical Technique}

Patients were taken to surgery on the day of their hospitalization. They were operated under spinal or general anesthesia in line with the decision taken by the patient and the anesthesiologist. In the operating room, the surgical area was shaved, and $1 \mathrm{gr}$ of cefazolin was given prophylactically to all patients during anesthesia induction. The patient's hip was placed in the Jack-knife position and was lateralized with the help of adhesive tapes on both sides to make the surgical field more visible (Figure 1a). Gluteal and sacral regions were prepared with the help of iodine solution. All diseased tissue was excised till the post sacral region with a simple elliptical incision made to include all pit and lateral fistula openings in the intergluteal region (Figure 1b). After excision, traction bands in the hip were released, and a drawing was made with a marker pen for the reconstruction with flap. An elliptical flap was drawn at the same length and width as the length of the excised area, regardless of which side it was prepared. The distance between the lateral lower end of the elliptic flap and the lower end of the excision area was set by leaving a distance as long as the length of the widest part of the excision area, contrary to the $1 \mathrm{~cm}$ distance described by Nessar et al. (Figure 1c). Again, contrary to Nessar et al., the flap was not prepared cutaneously but fasciocutaneously, including the fascia of the gluteus maximus muscle (Figure 1d). After the flap was completely released, it was transposed into the post sacral area (Figure 1e). After meticulous hemostasis, a hemovac drain was inserted to the surgical area. The subcutaneous tissue was then approached by 2-0 vicryl sutures. The skin was closed with intermittent matrix sutures with 2/0 prolene, and care was taken not to leave the nodes on the flap (Figure 1f).

\section{Follow Up}

Patients were discharged on the first post-operative day with antibiotics and painkillers. If the drainage was below $20 \mathrm{ml}$, the drain was removed during patient discharge, otherwise it was waited until the drainage decreased below $20 \mathrm{ml}$ in the outpatient clinic follow-up to remove the drain. In order to prevent sweating, wetting and maceration in the intergluteal sulcus, patients were advised to do wound dressings every day for a week and place a rolled gauze in the newly created intergluteal area during wound dressing. The patients were invited to outpatient clinic controls on postoperative $2^{\text {nd }}, 7^{\text {th }}$ and $12^{\text {th }}$ days for wound assessment and stitch removal. Following the first month after surgery, the patients were advised to have a laser epilation covering the back, waist and hip areas if possible or a monthly epilation with depilatory creams if not. Data of the patients including operation time, wound issues (infection, seroma, wound 

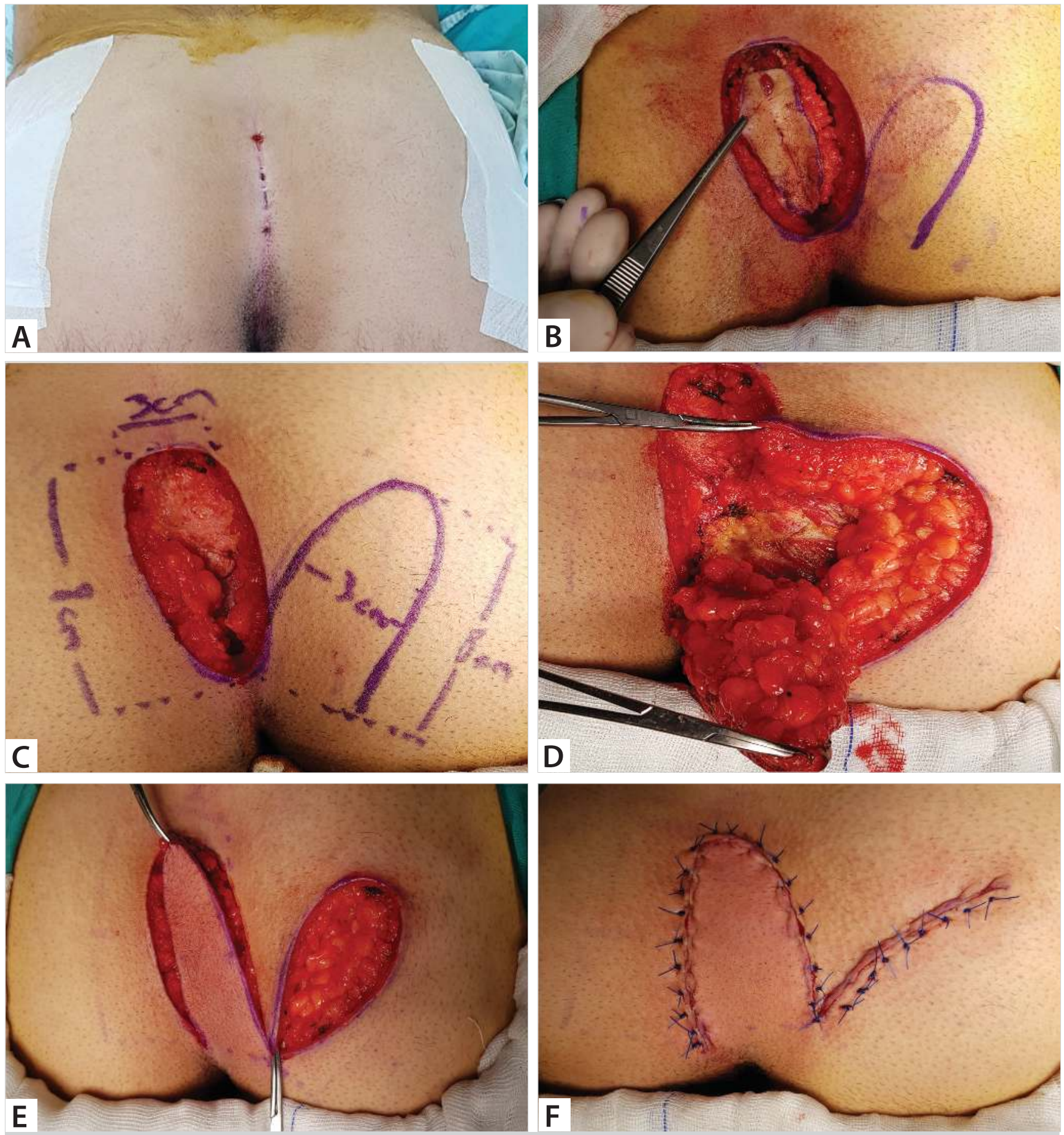

Figure 1. Fasciocutaneous elliptical rotation flap technique; a. Lateralization of the hip with the help of adhesive tapes, b. Simple elliptical excision, c. Flap preparation, d. Flap elevation, e. Transposition of the flap, f. Final view of the surgical area.

separation), time required to return to daily activities, complete healing time, and recurrence rates were recorded.

\section{Statistical Analyses}

Data were expressed as percentage, mean \pm standard error of the mean, or as median and interquartile range. All data were analyzed using the Statistical Package for Social Sciences 21 (SPSS Inc., Chicago, IL, USA) for Mac.

\section{RESULTS}

Of the 186 patients who were operated on for PSD and underwent FERF, 149 (80.1\%) were males and 37 (19.9\%) were females. Mean 
Table 1. Characteristics of the patients and the results of the fasciocutaneous elliptical rotation flap technique

\begin{tabular}{|l|c|}
\hline & FERF $(\mathbf{n}=\mathbf{1 8 6})$ \\
\hline Age & $23.6 \pm 4.4$ years \\
\hline Fex & $149(80.1 \%)$ \\
\hline BMI & $37(19.9 \%)$ \\
\hline Previous abscess attack & $24.2 \pm 9.7 \mathrm{~kg} / \mathrm{m}^{2}$ \\
\hline Type of anesthesia & $119(63.9 \%)$ \\
\hline Spinal & \\
\hline General & $147(79 \%)$ \\
\hline Operation time & $39(21 \%)$ \\
\hline Drain removal time & $43 \pm 13$ min. \\
\hline Complications & $2.20 \pm 1.18$ days \\
\hline Seroma & \\
Hematoma & $7(3.8 \%)$ \\
\hline Dermal ischemia & N/A \\
Infection & $1(0.5 \%)$ \\
Complete wound dehiscence & $2(1 \%)$ \\
Partial wound dehiscence & N/A \\
\hline Complete healing time & $5(3.2 \%)$ \\
\hline Recurrence & $13 \pm 3$ days \\
\hline Follow up time & N/A \\
\hline FERF: Fasciocutaneous elliptic rotation flap, BMI: Body mass index. \\
\hline
\end{tabular}

age of the patients was $23.6 \pm 4.4$. Mean body mass index (BMI) of the patients was $24.2 \pm 9.7 \mathrm{~kg} / \mathrm{m}^{2}$, and 119 (63.9\%) of the patients described a previous abscess attack. Complete healing time of the patients was $13 \pm 3$ days. One hundred and forty-seven (79\%) patients underwent spinal anesthesia and 39 (21\%) were operated under general anesthesia, and mean operative time was $43 \pm 13$ minutes. Mean time of the patients' drain removal was $2.20 \pm 1.18$ days. Mean follow-up time was 19 (6-37) months. There were no flap necrosis or ischemia, but we encountered dermal ischemia at the corner where the flap was removed in one patient, and the flap was reconstructed. In two patients (1\%) who developed postoperative infections, the wound was treated by removing several skin sutures and using antibiotics. Seroma developed in 7 (3.8\%) patients. Partial wound dehiscence occurred in 5 (3.2\%) patients, 4 of whom developed seroma and 1 developed dermal ischemia in the flap corner. None of the cases experienced hematoma or complete dehiscence. No recurrence was observed in postoperative follow-ups. Characteristics of the patients and results of the FERF technique are summarized in Table-1.

\section{DISCUSSION}

There are many operative and non-operative options for the treatment of PSD, but discussions about the optimal treatment is still ongoing. Although cosmetic results, length of hospital stay, and the amount of postoperative pain are important in ideal treatment, we are of the opinion that the surgical method should improve patient comfort as quickly as possible, provide early return to daily routines, should not require long-term wound care, re-surgery and intervention, and cause recurrence. Since the complications of the disease themselves and their treatments often require patients and caregivers to go to the office or hospital for wound care, it causes individuals to lose time from work or school (5).

Primary excision and lay open procedure, which have been commonly used before, have a very long complete healing period, and yet they have substantial levels of recurrence (18). Primary closure of the wound is a simple method, but due to the continuing natal cleft, it has a high rate of recurrence (19). Nowadays, it is widely agreed that off-midline (rather than midline) skin closure should become the preferred treatment after wide excision of the sinuses. The evidence of this concept has been shown by several randomized controlled studies and a subsequent meta-analysis (15).

Due to the negative consequences of midline closure techniques, Karydakis and Bascom have published their techniques that provide off-midline closure and noted significant improvements in morbidity and recurrence rates $(8,13)$.

Rotation flap techniques have been successfully tried in patients in the following process, as procedures that flatten the intergluteal sulcus depth, bring the suture line to an area other than the midline, and reduce tissue tension seem advantageous. Today, the most commonly used plasty methods are Limberg flap, $\mathrm{V}-\mathrm{Y}$ plasty, and Z plasty (5).

The Z-plasty method was first introduced by Monro and MacDermot for PSD treatment (20). This treatment has the disadvantage that some of the scar tissue persists in the midline, which is the leading cause of recurrence. With the Z-plasty technique, Lamke et al. have noticed a 16\% recurrence rate (21).

The $V$-Y advancement flap can cover the defects up to $10 \mathrm{~cm}$ in size. In some studies, it has been shown that this technique provides good healing and minimal wound complication and good recurrence rates (22). Furthermore, Berkem et al. have reported better results with off-midline $V$ - $Y$ plasty rather than midline related $\mathrm{V}-\mathrm{Y}$ plasty (23).

Limberg flap and its modifications are the most commonly known and accepted methods for PSD treatment with flap technique (12). Cihan et al. have reported that reconstruction with the Limberg flap gives better results than primary closure, and the modified Limberg flap (MLF) technique corrects the weaknesses of the standard limber flap and gives even better results (24). 

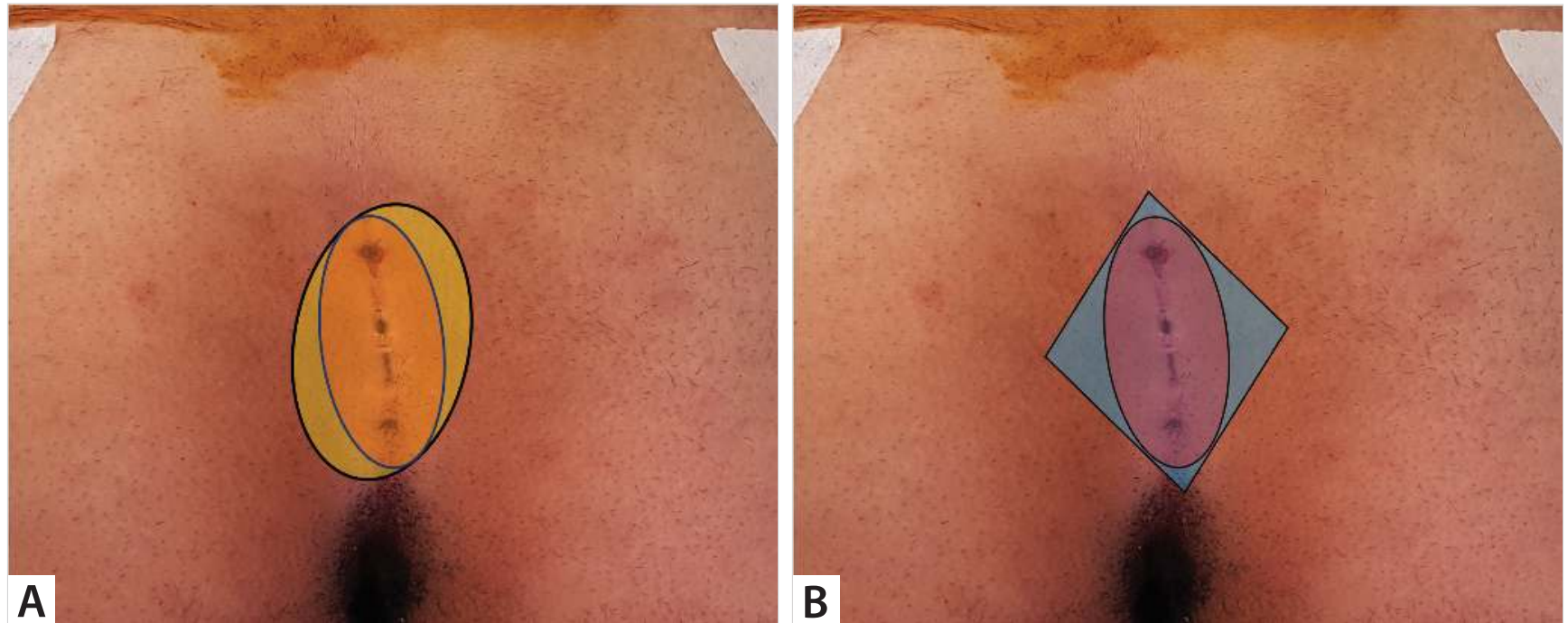

Figure 2. Comparison of the resection areas required by the types of surgery to excise the same sized pilonidal sinus; a. Modified elliptical rotation flap technique (Yellow area) vs. Fasciocutaneous elliptical rotation flap technique (Red area), b. Limberg flap technique (Blue area) vs. Fasciocutaneous elliptical rotation flap technique (Red area).

In order to correct the acute angling end points in other flap techniques, which are the causes of tissue ischemia, dehiscence and infection, Nessar et al. have described the ERF technique with $0 \%$ recurrence and short hospital stay (14). ERF technique contains cutaneous flap with $1 \mathrm{~cm}$ pivot point in its lower corner, which has caused concerns about flap blood supply (25). Dizen et al. have modified this technique for its weak point, which has an end point in the natal cleft that causes maceration and prolonged wound healing with an oblique elliptical excision and an opposite-sided flap, and they have also reported 0\% recurrence again (16). Later on, Yoldaş et al. have compared MERF with MLF and reported no significant difference between the groups by means of flap ischemia, dehiscence, infection, pain and quality of life; however, MERF has proven shorter operative time and improved cosmetic outcomes. In addition, Yoldaş et al. have not reported any recurrence in the MERF group (17).

Fasciocutaneous flaps have been used for many decades in reconstructive surgery. Fasciocutaneous flaps consisting of skin, fat, and deep fascia have been successfully used to close off a variety of limb, trunk, and head and neck defects. These flaps provide many advantages: they restore blood flow, increase healing rate, and help restore function faster (26). In this study, we preferred a fasciocutaneous flap for the reconstruction of the excision area to remove the limitations of the ERF in the treatment of PSD. In addition, we aimed to contribute to the flap blood supply by leaving the root width of the flap as wide as the distance of the excision area, and also to reach the promising results of the ERF technique. As a result of our study, we obtained a $0 \%$ recurrence rate similar to previous studies and did not experience flap ischemia or necrosis in any of our patients. We think that the advantage of our technique compared to the MERF tech- nique is that it requires less resection area (Figure 2a), especially in complicated cases containing bilateral lateral fistula openings, and allows flap preparation from any side if desired. We believe that the superiority of our FERF technique over MLF technique also requires a smaller surface area (Figure 2b) compared to the rhomboid excision area of the elliptical excision area and thus, has better cosmetic results and faster recovery.

\section{CONCLUSION}

In conclusion, it is to our belief that fasciocutaneous elliptical rotation flap is a method that has follow-up results similar to both the ERF technique and its modification and can be safely preferred in the treatment of pilonidal sinus with its other advantages.

Ethics Committee Approval: Ethic committee approval was received for this study Committee on Instutional Ethics of Liv Hospital (2020-006)

Peer-review: Externally peer-reviewed.

Author Contributions: Concept - E.G.; Design - E.G.; Supervision - E.G.; Resource - E.G.; Materials - E.G.; Data Collection and/or Processing - E.G.; Analysis and Interpretation - E.G.; Literature Review - E.G.; Writing Manuscript E.G.; Critical Reviews - E.G.;

Conflict of Interest: The authors have no conflicts of interest to declare.

Financial Disclosure: The authors declared that this study has received no financial support.

\section{REFERENCES}

1. Mayo $\mathrm{OH}$. Observations on injuries and diseases of the rectum. London: Burgess and Hill; 1833. pp. 45-6. [CrossRef]

2. Yildiz T, Ilce Z, Kücük A. Modified Limberg flap technique in the treatment of pilonidal sinus disease in teenagers. J Pediatr Surg 2014; 49: 1610-3. [CrossRef] 
3. Patey DH, ScarffRW. Pathology of postanal pilonidal sinus; its bearing on treatment. Lancet 1946; 2: 484-6. [CrossRef]

4. Søndenaa K, Andersen E, Nesvik I, Søreide JA. Patient characteristics and symptoms in chronic pilonidal sinus disease. Int I Colorectal Dis 1995; 10: 39-42. [CrossRef]

5. Humphries $A E$, Duncan JE. Evaluation and management of pilonidal disease. Surg Clin North Am 2010; 90: 113-24. [CrossRef]

6. Saber A, Bayumi EK. Sacrococcygeal Pilonidal Sinus Disease. Biofilm, Pilonidal Cysts and Sinuses 2020; 215-30. [CrossRef]

7. Yucesan S, Dindar H, Olcay I, Okur H, Kilicaslan S, Ergoren Y, et al. Prevalence of congenital abnormalities in Turkish school children. Eur J Epidemiol 1990; 9: 373-80. [CrossRef]

8. Karydakis GE. Easy and successful treatment of pilonidal sinus after explanation of its causative process. Aust N Z J Surg 1992; 62: 385-9. [CrossRef]

9. Doll D, Friederichs J, Dettmann H, Boulesteix AL, Duesel W, Petersen S. Time and rate of sinus formation in pilonidal sinus disease. Int J Colorectal Dis 2008; 23: 359-64. [CrossRef]

10. Armstrong JH, Barcia PJ. Pilonidal sinus disease: the conservative approach. Arch Surg 1994; 129: 914-7. [CrossRef]

11. Hodges RM. Pilonidal sinus. Boston Med Surg J 1880; 103: 485-6. [CrossRef]

12. Sevinç B. Treatment of Pilonidal Disease. Biofilm, Pilonidal Cysts and Sinuses 2020; 251-4. [CrossRef]

13. Bascom J. Pilonidal disease: origin from fol- licles of hairs and results of follicle removal as treatment. Surgery 1980; 87: 567-72. [CrossRef]

14. Nessar G, Kayaalp C, Seven C. Elliptical rotation flap for pilonidal sinus. Am J Surg 2004; 187: 300-3. [CrossRef]

15. Kitchen P. Pilonidal sinus: has off-midline closure become the gold standard? ANZ J Surg 2009; 79: 4-5. [CrossRef]

16. Dizen H, Yoldas O, Yıldiz M, Cilekar M, Dilektaslı E. Modified elliptical rotation flap for sacrococcygeal pilonidal sinus disease. ANZ J Surg 2014; 84: 769-71. [CrossRef]
17. Omer Y, Hayrettin D, Murat C, Mustafa Y, Evren, D. Comparison of modified limberg flap and modified elliptical rotation flap for pilonidal sinus surgery: a retrospective cohort study. Int I Surg 2015; 16: 74-7. [CrossRef]

18. Notaras MJ. A review of three popular methods of treatment of postanal (pilonidal) sinus disease. Br J Surg 1970; 57: 886-90. [CrossRef]

19. Petersen S, Koch R, Stelzner S, Wendlandt TP, Ludwig K. Primary closure techniques in chronic pilonidal sinus: a survey of the results of different surgical approaches. Dis Colon Rectum 2002; 45: 1458-67. [CrossRef]

20. Monro SR, MacDermot FT. The elimination of causal factors in pilonidal sinus treated by Z-plasty. Br J Surg 1965; 52: 177-81. [CrossRef]

21. Lamke LO, Larsson J, Nylén B. Treatment of pilonidal sinus by radical excision and reconstruction by rotation flap surgery of Z-plasty technique. Scand J Plast Reconstr Surg 1979; 13: 351-3. [CrossRef]

22. Schoeller T, Wechselberger G, Otto A, Papp C. Definite surgical treatment of complicated recurrent pilonidal disease with a modified fasciocutaneous V-Y advancement flap. Surgery 1997; 121: 258-63. [CrossRef]

23. Berkem H, Topaloglu S, Ozel H, et al. V-Y advancement flap closures for complicated pilonidal sinus disease. International journal of colorectal disease 2005; 20: 343-8. [CrossRef]

24. Cihan A, Mentes BB, Tatlicioglu E, Ozmen S, Leventoglu S, Ucan BH. Modified Limberg flap reconstruction compares favourably with primary repair for pilonidal sinus surgery. ANZ journal of surgery 2004; 74: 238-42. [CrossRef]

25. Yazicioglu B, Polat C, Gokce Ö. Elliptical rotation flap for pilonidal sinus. The American Journal of Surgery 2006; 191: 142. [CrossRef]

26. Stecco C, Tiengo C, Stecco A, Porzionato A, Macchi V, Stern R, De Caro $R$. Fascia redefined: anatomical features and technical relevance in fascial flap surgery. Surgical and Radiologic Anatomy 2013; 35: 36976. [CrossRef] 


\section{ORIJINAL ÇALIŞMA-ÖZET}

Turk J Surg 2020; 36 (3): 310-316

\section{Pilonidal sinüs hastalığında fasyokutan eliptik rotasyon flebi ve sonuçları}

Emre Gündoğdu ${ }^{1}$

${ }^{1}$ Liv Hospital Ankara, Genel Cerrahi, Ankara, Türkiye

\section{ÖZET}

Giriş ve Amaç: Sakrokoksigeal pilonidal sinus hastalığı özellikle Orta Doğu Kafkasyalılarında yaygın bir hastalıktır. Yüz bin popülasyonda $12-26$ insidansında rapor edilmiştir. Daha önceleri konjenital orijinli etiyolojik nedenlerden kaynaklandığı düşünülmekteyken, günümüzde edinilmiş bir hastalık olduğu kabul edilmektedir. Pilonidal sinüs hastalığının ideal tedavisiyle ilgili hala bir fikir birliği yoktur. Eliptik rotasyon flebi ilk olarak Nessar tarafından pilonidal sinüs cerrahisinde tanımlanmış ve başarılı sonuçlar bildirmiştir, ancak bazı zayıf noktaları vardır. Bu çalışmanın amacı fasiokütanöz eliptik rotasyon flep tekniğini ve bulgularını retrospektif olarak paylaşmaktır.

Gereç ve Yöntem: 2013-2018 yılları arasında pilonidal hastalık nedeniyle opere edilen ve fasiokütanöz eliptik rotasyon flebi uygulanan 186 hasta (149'u erkek, 37'si kadın) çalışmaya dahil edildi. Ameliyat süresi, yara problemleri (infeksiyon, seroma, yara ayrışması), günlük aktivitelere dönmeleri için gereken süre, tam iyileşme süresi ve nüks oranları da dahil olmak üzere hastaların verileri retrospektif olarak kaydedildi.

Bulgular: Hastaların tam iyileşme sürelerinin ortalaması $13 \pm 3$ gün, ortalama takip süresi 19 (6-37) aydı. Ortalama ameliyat süresi $43 \pm 13$ dakikaydı. Dren çekilme süresi ortalama 2,20 $\pm 1,18$ gündü. Hastaların hiçbirisinde flep nekrozu veya iskemi gelişmedi. İki hastada (\%1) ameliyat sonrası infeksiyon gelişti. Yedi hastada $(\% 3,8)$ seroma gelişti. Beş hastada $(\% 3,2)$ kısmi yara ayrımı meydana geldi. Olguların hiçbirinde hematom veya tam yara ayrışması gelişmedi. Postoperatif takiplerde nüks görülmedi.

Sonuç: Fasiokütanöz eliptik rotasyon flebi, hem eliptik rotasyon flebi tekniğine hem de onun modifikasyonuna benzer takip sonuçlarına sahip bir yöntemdir ve pilonidal sinüs tedavisinde beraberinde getirdiği diğer avantajlar ile güvenle tercih edilebilir bir yöntemdir.

Anahtar Kelimeler: Pilonidal sinus disease, elliptical rotation flap, limberg flap, rotation flap

Doi: $10.47717 /$ turkjsurg.2020.4917 